\title{
1 Impact of organic acids on chloride depletion of inland 2 transported sea spray aerosols
}

3 Bojiang $\mathrm{Su}^{1}$, Zeming $\mathrm{Zhuo}^{1}$, Yuzhen $\mathrm{Fu}^{2,3}$, Wei $\mathrm{Sun}^{2,3}$, Ying $\mathrm{Chen}^{1}$, Xubing $\mathrm{Du}^{1}$,

4 Yuxiang Yang ${ }^{2,3}, \mathrm{Si} \mathrm{Wu}^{1}$, Fugui Huang ${ }^{4}$, Duohong $\mathrm{Chen}^{5}$, Lei Li ${ }^{1, *}$, Guohua Zhang ${ }^{2,6}$,

5 Xinhui $\mathrm{Bi}^{2,6}$, and Zhen Zhou ${ }^{1}$

$6{ }^{1}$ Guangdong Provincial Engineering Research Center for On-line Source Apportionment

7 System of Air Pollution, Institute of Mass Spectrometry and Atmospheric Environment, Jinan

8 University, Guangzhou 510632, PR China

$9{ }^{2}$ State Key Laboratory of Organic Geochemistry and Guangdong Key Laboratory of

10 Environmental Protection and Resources Utilization, Guangzhou Institute of Geochemistry,

11 Chinese Academy of Sciences, Guangzhou 510640, PR China

$12{ }^{3}$ University of Chinese Academy of Sciences, Beijing 100039, PR China

$13{ }^{4}$ Guangzhou Hexin Analytical Instrument Limited Company, Guangzhou 510530, PR China

$14{ }^{5}$ State Environmental Protection Key Laboratory of Regional Air Quality Monitoring,

15 Guangdong Environmental Monitoring Center, Guangzhou 510308, PR China

$16{ }^{6}$ Guangdong-Hong Kong-Macao Joint Laboratory for Environmental Pollution and Control,

17 Guangzhou Institute of Geochemistry, Chinese Academy of Sciences, Guangzhou 510640, PR

18 China

19

$20 *$ *orrespondence to: Lei Li (lileishdx@163.com) 
https://doi.org/10.5194/acp-2020-443

Preprint. Discussion started: 8 June 2020

(c) Author(s) 2020. CC BY 4.0 License.

(c) (i)

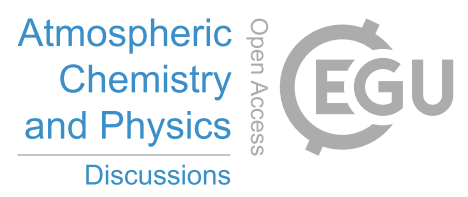

\section{Highlights}

22 1. Half of the sea salt aerosol (SSA) particles could be assigned as the biological origin.

232 . Organic acids considerably contribute to chloride depletion of SSA particles.

243 . Biological organic coatings may inhibit heterogeneous reactions of SSA particles. 
Abstract. Heterogeneous reactions on sea spray aerosols (SSA) are the main pathway to drive the circulation of chlorine, nitrogen, and sulfur in the atmosphere. The release of $\mathrm{Cl}$ will significantly affect the physicochemical properties of SSA. However, the impact of organic acids and mixing state on chloride depletion of SSA is still unclear. Hence, the size and chemical composition of individual SSA particles during the East Asian summer monsoon were investigated by a single particle aerosol mass spectrometer (SPAMS). According to the chemical composition, SSA particles were classified into SSA-Aged, SSA-Bio and SSA-Ca. In comparison to the aged Na-rich SSA particles (SSA-Aged), some additional organic species related to biological origin were observed in SSA-Bio, and each of two types accounts for approximately $50 \%$ of total SSA particles. SSA-Ca may associated with organic shell of Na-rich SSA particles, which only accounts for $\sim 3 \%$. Strongly positive correlations between $\mathrm{Na}$ and organic acids (including formate, acetate, propionate, pyruvate, oxalate, malonate, succinate, and glutarate) were observed for the SSA-Aged $\left(\mathrm{r}^{2}=0.52, p<0.01\right)$ and SSA-Bio $\left(\mathrm{r}^{2}=\right.$ $0.61, p<0.01)$, indicating the significance of organic acids in the chloride depletion during inland transport. The contribution of these organic acids to the chloride depletion is estimated to be up to $34 \%$. Interestingly, the degree of chloride depletion is distinctly different between SSA-Aged and SSA-Bio. It is most probably attributed to the associated organic coating in the SSA-Bio particles, which inhibit the displacement reactions between acids and chloride. As revealed from the mixing state of SSA-Bio, $\mathrm{Cl} / \mathrm{Na}$ ratio increases with increasing phosphate and organic nitrogen, which is known to originate from biological activities. This finding provides some basis for the 
https://doi.org/10.5194/acp-2020-443

Preprint. Discussion started: 8 June 2020

(C) Author(s) 2020. CC BY 4.0 License.

47 improvement of modeling simulations in chlorine circulation and a comprehensive

48 understanding of the effects of organics on chloride depletion of SSA particles.

49 Keywords:

50 Sea spray aerosols; individual particles; chloride depletion; mixing state; organic acids. 
Thessions

\section{$51 \quad 1$ Introduction}

As one of the largest natural sources of aerosols, sea spray aerosols (SSA) have a global flux of 2000-10000 $\mathrm{Tg} \mathrm{yr}^{-1}$ (Gantt and Meskhidze, 2013) and global average distribution of $10.1 \mu \mathrm{g} \mathrm{m}^{-2}$ (Ma et al., 2008). SSA are highly complex mixtures, and the chemical composition and mixing state of original SSA depends on the components of local seawater and the mechanisms of formation (Wang et al., 2017). While fresh SSA particles contain approximately $90 \%$ sodium chloride $(\mathrm{NaCl})$ in mass, multiphase reactions considerably affect the chemical composition and mixing state, and subsequently, the physical and chemical properties of SSA. The multiphase reactions of SSA, as have been widely reported in field experiments and laboratory studies (Ault et al., 2014; Ghorai et al., 2014; Ryder et al., 2015; Trueblood et al., 2016; Bondy et al., 2017; Martin et al., 2017; Bertram et al., 2018), drive the circulation of elements (e.g., $\mathrm{C}, \mathrm{O}, \mathrm{N}, \mathrm{S}, \mathrm{P}, \mathrm{Cl}$ ) affecting tropospheric chemistry and global ecosystem (FinlaysonPitts, 2003).

As one of the most important reactions, chloride depletion, as shown in R1, in SSA by interacting with acidic species modifies the physicochemical properties of SSA.

$$
\mathrm{HA}_{\left(g_{\text {or } a q)}\right.}+\mathrm{NaCl}_{(a q \text { or } s)} \rightarrow \mathrm{NaA}_{(a q \text { or } s)}+\mathrm{HCl}_{\left(g_{\text {or }} a q\right)}
$$

where $\mathrm{NaCl}$ represents the major component of SSA, and HA represents acidic species (e.g., $\mathrm{HNO}_{3}, \mathrm{H}_{2} \mathrm{SO}_{4}$, and organic acids). Generally, inorganic acids are considered as the major contributors to chloride depletion in SSA (Dasgupta et al., 2007; Laskin et al., 2012; Chi et al., 2015), represented as: 


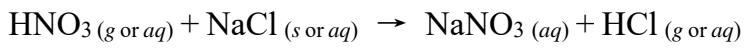

$$
\begin{aligned}
& \mathrm{H}_{2} \mathrm{SO}_{4}\left(g_{\text {or } a q)}+\mathrm{NaCl}_{(\text {s or } a q)} \rightarrow \mathrm{Na}_{2} \mathrm{SO}_{4}(a q)+\mathrm{HCl}_{(g \text { or } a q)}\right.
\end{aligned}
$$

However, growing evidence indicates that inorganic acids cannot fully explain the chloride depletion (Laskin et al., 2012). It is therefore proposed that organic acids should be included to further explain the mechanism of chlorine depletion in aged SSA (Ault et al., 2013; Wang and Laskin, 2014; Wang et al., 2015). Similarly, the heterogeneous reactions on SSA with organic acids (R-COOH) can be described as:

$$
\begin{aligned}
& \mathrm{R}-\mathrm{COOH}\left(g_{\text {or } a q)}+\mathrm{NaCl}_{(\text {s or } a q)} \rightarrow \mathrm{R}-\mathrm{COONa}_{(a q)}+\mathrm{HCl}_{(g \text { or } a q)}\right. \\
& \mathrm{NaNO}_{3(a q)}+\mathrm{R}-\mathrm{COOH}\left(g_{\text {or }} a q\right) \rightarrow \mathrm{HNO}_{3}\left(g_{\text {or }} a q\right)+\mathrm{R}-\mathrm{COONa}\left(s_{\text {or }} a q\right)
\end{aligned}
$$

(s, solid; $a q$, aqueous; and $g$, gaseous)

The physicochemical properties of SSA could be substantially altered through the production of organic salts (Trueblood et al., 2016; Bertram et al., 2018). With ubiquitous existence in the atmosphere, some typical organic acids, such as formic acid, acetic acid, and oxalic acid, may potentially contribute to chloride depletion. Mochida et al. (2003) suggested that organic acids (e.g., oxalic acid and succinic acid) should be considered in the models in order to predict chloride depletion accurately. Through investigating the interactions between the pure $\mathrm{NaCl}$ and carboxylic acids in the laboratory, Laskin et al. (2012) even suggested interactions between carboxylic acids and $\mathrm{NaCl}$ was the main contribution of chloride depletion. Consistently, Ghorai et al. (2014) observed that some dicarboxylic acids might cause obvious chloride depletion under a specific meteorological condition. These dicarboxylic acids (e.g., malonic acid and succinic acid) are ubiquitous in urban and marine aerosols (Kawamura and Bikkina, 
2016), which may come from the polluted continental outflow and the open ocean (Bikkina et al., 2015).

Given the potential contribution of organic acids to the chloride depletion, the understanding of the relative contribution and the influencing factors is still unclear. The investigation of factors that affect chloride depletion is indispensable to understand the ageing process of SSA and the ability to serve as cloud condensation nuclei $(\mathrm{CCN})$ (Drozd et al., 2014; Wang et al., 2015). The morphology of fresh SSA particles is coreshell structure, which consists of salt-core dominated by sodium chloride and outer shell covered by $\mathrm{K}^{+}, \mathrm{Ca}^{2+}, \mathrm{Mg}^{2+}, \mathrm{SO}_{4}^{2-}, \mathrm{Cl}^{-}$and organic components (Laskin et al., 2012; Collins et al., 2014; Chi et al., 2015). These organic components such as alkanes, fatty acids, sugars, dicarboxylic acids and phosphate may emitted from phytoplankton and bacteria in the sea surface microlayer (SSML) (Gaston et al., 2010; Bikkina et al., 2015; Cochran et al., 2017a; Cochran et al., 2017b; Wang et al., 2017), and the chemical composition and size distribution of SSA particles could be greatly changed by wave breaking. In recent literature, organic coatings on the particles resulted from atmospheric oxidation of hydrocarbons of biogenic and anthropogenic origin may significantly regulate uptake of $\mathrm{N}_{2} \mathrm{O}_{5}$ (Folkers et al., 2003; Ryder et al., 2015).

In the present study, a single particle aerosol mass spectrometer (SPAMS) was used to investigate the particle size, chemical composition and ageing degree of individual SSA particles after long-range inland transport during the summer monsoon, to reveal the relative contribution of organic acids on chloride depletion and the influencing factors. The displacement reactions on the SSA particles with various types 
116 of organic acids are considered, and the results suggest a significant impact of organic

117 acids on chloride depletion during inland transport. The influence of biogenic organics

118 in the chloride depletion was also discussed.

\section{Materials and Methods}

120

\subsection{Field site description}

The sampling site is located at Nanling national background station (Mt. Tianjing, $24^{\circ} 41^{\prime} 56^{\prime \prime} \mathrm{N}, 112^{\circ} 53^{\prime} 56^{\prime \prime} \mathrm{E} ; 1690 \mathrm{~m}$ a.s.1.), which was approximately $350 \mathrm{~km}$ north of the South China Sea and $200 \mathrm{~km}$ north of the Pearl River Delta (PRD) region. It is also surrounded by a national park forest $\left(273 \mathrm{~km}^{2}\right)$, where there were barely anthropogenic pollutants. However, under the influence of the East Asian summer monsoon, the air mass originated from the South China Sea might cross the PRD region to the sampling site. As can be seen in Supplement Fig. S1, four major cluster back trajectories of air masses originated from the South China Sea and Indo China Peninsula transported across inland regions to the sampling site within $72 \mathrm{~h}$. During the sampling period, the average relative humidity was $87 \%$, the average temperature was $26.3^{\circ} \mathrm{C}$, the wind direction was mainly southwesterly, and the average wind speed was $10 \mathrm{~m} \mathrm{~s}^{-1}$. More detailed information on the meteorological data can be found in Supplement Fig. S2.

\subsection{Instrumentation}

Individual particles were analyzed using a SPAMS (Hexin Analytical Instrument Co., Ltd., China) from 11 May to 3 June 2018. The SPAMS was used to on-line measure 
136 the size and chemical composition of individual particles. The design and principles of

137 SPAMS have been reported in detail previously (Li et al., 2011). Briefly, the aerosols are drawn into the aerodynamics lens. Then the collimated particles beam through two continuous laser beams (Nd: YAG laser, $532 \mathrm{~nm}$ ) with a pace of $6 \mathrm{~cm}$. The obtained time of flight and velocity are corresponding to the vacuum aerodynamic diameter. The velocity of an individual particle is applied to trigger the pulse laser (Nd: YAG laser, $266 \mathrm{~nm})$. Subsequently, the generated ion fragments are detected by a bipolar time-offlight mass spectrometer. Standard polystyrene latex spheres of 0.2-2.2 $\mu \mathrm{m}$ were used to calibrate vacuum aerodynamic particle sizes $\left(d_{v a}\right)$ of the measured individual 145 particles. one is a ground-based counterflow virtual impactor (GCVI model 1205, Brechtel Manufacturing Inc., USA), sampling the cloud residual particles, dried from cloud droplets (with size larger than $8 \mu \mathrm{m}$ ) during cloud event (i.e., when the relative humidity was higher than $95 \%$ and the visibility was lower than $3 \mathrm{~km}$ ) (Zhang et al., 2017). The other one is a $\mathrm{PM}_{2.5}$ sampling inlet, delivering fine particles during cloud free periods.

\subsection{Classification of SSA}

The general characteristic peaks of SSA particles include $m / z 23[\mathrm{Na}]^{+}, 39[\mathrm{~K}]^{+}$, $46\left[\mathrm{Na}_{2}\right]^{+}, 62\left[\mathrm{Na}_{2} \mathrm{O}\right]^{+}, 63[\mathrm{Na} 2 \mathrm{OH}]^{+}, 81\left[\mathrm{Na}_{2}{ }^{35} \mathrm{Cl}\right]^{+}$and $83\left[\mathrm{Na}_{2}{ }^{37} \mathrm{Cl}\right]^{+}$(Collins et al., 2014; Arndt et al., 2017; Martin et al., 2017). There are some additional organic peaks 
$157\left[\left(\mathrm{C}_{2} \mathrm{H}_{5}\right)_{2} \mathrm{NH}_{2}\right]^{+},-26[\mathrm{CN}]^{-},-42[\mathrm{CNO}]^{-},-63\left[\mathrm{PO}_{2}\right]^{-},-79\left[\mathrm{PO}_{3}\right]^{-}$, etc.), besides sodium-

158 related peaks in SSA particles (Ault et al., 2014; Sultana et al., 2017b). In this study,

159 SSA particles were identified by the presence of peaks at $m / z 23,46,62,63,81$ and 83 , which was coincident with the previous study at the same site reported by Lin et al. (2019). In addition, these organic signals are also considerable for identification of SSA

162 particles, when the above sodium related peaks exist.

A total of $\sim 2$ million detected particles were clustered into several groups using an Adaptive Resonance Theory neural network (ART-2a) (Song and Hopke, 1999) with a vigilance factor of 0.75 , a learning rate of 0.05 and a maximum of 20 iterations. Based on the above representative peaks, $\sim 50000$ SSA particles were identified. Three types of SSA particles with distinct mass spectral characteristics were obtained, including $\sim 25000$ SSA-Aged, 25000 SSA-Bio and 1500 SSA-Ca, respectively. We note that the mass spectral characteristics of SSA for the cloud residual particles ensemble those for the cloud-free particles. And therefore, we focus on the influence of long-range transport, rather than in-cloud process, on the modification of SSA.

\section{Results and discussion}

\subsection{General characteristics of inland transported SSA particles}

Figure 1 provides the averaged positive and negative ion mass spectra of three types of SSA particles. SSA-Aged is characterized by prominent ion signature for $\mathrm{m} / \mathrm{z}$ at $23[\mathrm{Na}]^{+}, 39[\mathrm{~K}]^{+}, 40[\mathrm{Ca}]^{+}, 46\left[\mathrm{Na}_{2}\right]^{+}, 62\left[\mathrm{Na}_{2} \mathrm{O}\right]^{+}$and $63\left[\mathrm{Na}_{2} \mathrm{OH}\right]^{+}$. Some contributions from $\mathrm{m} / \mathrm{z} 24[\mathrm{Mg}]^{+}, 56[\mathrm{Fe}]^{+}$or $56[\mathrm{CaO}]^{+}, 81\left[\mathrm{Na}_{2}{ }^{35} \mathrm{Cl}\right]^{+}, 83\left[\mathrm{Na}_{2}{ }^{37} \mathrm{Cl}\right]^{+}$, 

characteristics are similar to those in previous literature (Hughes et al., 2000; Collins et al., 2014; Sultana et al., 2017a). This type of SSA particles with a significant ion marker of $\mathrm{Na}$ is typically represented as Na-rich sea salt particles. In the negative ion spectra, abundant nitrate were observed due to the ratio of $\mathrm{m} / \mathrm{z}$ at $-46\left[\mathrm{NO}_{2}\right]^{-},-62\left[\mathrm{NO}_{3}\right]^{-}$, and $147\left[\mathrm{Na}\left(\mathrm{NO}_{3}\right)_{2}\right]^{-}$, in contrast to weak chlorine ion signal at $\mathrm{m} / \mathrm{z}-35\left[{ }^{35} \mathrm{Cl}\right]^{-}$and $-37\left[{ }^{35} \mathrm{Cl}\right]^{-}$, indicating that the particles have undergone partial but not fully atmospheric ageing (Hughes et al., 2000; Sultana et al., 2017b). Several peaks are assigned as organic acids, such as formate at $\mathrm{m} / \mathrm{z}-45\left[\mathrm{HCO}_{2}\right]^{-}$, acetate at $\mathrm{m} / \mathrm{z}-59\left[\mathrm{C}_{2} \mathrm{H}_{3} \mathrm{O}_{2}\right]^{-}$, propionate at $\mathrm{m} / \mathrm{z}-73$ $-103\left[\mathrm{C}_{3} \mathrm{H}_{3} \mathrm{O}_{4}\right]^{-}$, succinate at $\mathrm{m} / \mathrm{z}-117\left[\mathrm{C}_{4} \mathrm{H}_{5} \mathrm{O}_{4}\right]^{-}$, and glutarte at $\mathrm{m} / \mathrm{z}-131\left[\mathrm{C}_{5} \mathrm{H}_{7} \mathrm{O}_{4}\right]^{-}$ (Lin et al., 2019), which may be related to algal activity in the SSML or conversion of second organic aerosols (SOAs) in the atmosphere (O'Dowd et al., 2014). (i.e., organic nitrogen and phosphate), besides the general characteristics of the SSAAged particles (Prather et al., 2013; Guasco et al., 2014). While these markers might also be associated with dust (Zawadowicz et al., 2017), it is most likely attributed to biological markers herein, since there is negligible ion marker (e.g., $\mathrm{Al}, \mathrm{Ti}, \mathrm{Si}$ ) for dust. Distinct characteristics of amines $\left(58\left[\mathrm{C}_{2} \mathrm{H}_{5} \mathrm{NHCH}_{2}\right]^{+}, 59\left[\mathrm{~N}\left(\mathrm{CH}_{3}\right)_{3}\right]^{+}\right)$were presented in the positive spectra, which is similar to the results in a prior laboratory study (Sultana et al., 2017a). Besides, the source of amines could also be influenced by the formation 
of secondary species (such as animal husbandry and biomass burning) during transport

201

202

203

204

205

206

207

208 (Cheng et al., 2018). The organic nitrogen (i.e., $-26[\mathrm{CN}]^{-},-42[\mathrm{CNO}]^{-}$) has been assigned to the ionization of amino acids in previous studies (Abneesh et al., 2005; Czerwieniec. et al., 2005). Phosphate peaks at $\mathrm{m} / \mathrm{z}-63\left[\mathrm{PO}_{2}\right]^{-}$and $-79\left[\mathrm{PO}_{3}\right]^{-}$are likely assigned as the ionization of components such as phospholipids in biological cells (Fergenson, 2004; Collins et al., 2013; Cochran et al., 2017a; Cochran et al., 2017b; Nguyen et al., 2017). It is noted that SSA-Bio should be regarded as the SSA population influenced by biological activity (Prather et al., 2013). In addition, the peaks of $\mathrm{m} / \mathrm{z} 56$ represents $[\mathrm{CaO}]^{+} /[\mathrm{KOH}]^{+}$or $\left[{ }^{56} \mathrm{Fe}\right]^{+}$. In contrast to SSA-Aged, those aforementioned organic acids exhibited higher peak signal in SSA-Bio. Similar to SSA-Aged, inorganic acids $\left(-46\left[\mathrm{NO}_{2}\right]^{-},-62\left[\mathrm{NO}_{3}\right]^{-}\right.$and $\left.-97\left[\mathrm{HSO}_{4}\right]^{-}\right)$with strong ion signals were also observed. Despite of the different mass spectral pattern, the behavior and inland transport of SSA-Aged and SSA-Bio may be similar. As can be seen in Fig. S1, the relative proportions of them keep stable in the different air masses. They also exhibit similar size distribution, concentrating in size range of 0.4-0.7 $\mu \mathrm{m}$ and peaking around $0.5 \mu \mathrm{m}$ (Fig. S3).

SSA-Ca is identified by relatively higher contributions from calcium-related compounds at $m / z 40[\mathrm{Ca}]^{+}, 56[\mathrm{CaO}]^{+}, 57[\mathrm{CaOH}]^{+}, 75\left[\mathrm{Ca}^{35} \mathrm{Cl}_{2}\right]^{+}, 77\left[\mathrm{Ca}^{37} \mathrm{Cl}_{2}\right]^{+}$, and $113\left[(\mathrm{CaO})_{2} \mathrm{H}\right]^{+}$, whereas associated with smaller sodium peak than other types. The negative spectra are dominated by nitrate, sulfate, organic nitrogen, phosphate and chloride. This SSA population has been previously classified as "organic-carbondominated (OC)" (Prather et al., 2013; Collins et al., 2014), likely resulted from the 
coating of Na-rich particles through crystallization and precipitation (Sultana et al.,

223 2017a; May et al., 2018). The mass spectral characteristics of the Ca-rich SSA particles are quite similar to those of lake spray aerosols (Axson et al., 2016; May et al., 2018). covered in the following discussions.

\subsection{Contribution of organic acids to the chloride depletion in the SSA particles}

The linear correlations based on peak area between $\mathrm{Na}$ and chloride, sulfate, nitrate, and organic acids in the SSA-Aged and SSA-Bio particles are shown in Fig. 2. As expected, there are strong correlations between $\mathrm{Na}$ and nitrate in both the SSA-Aged $\left(r^{2}=0.79, p<0.01\right)$ and SSA-Bio $\left(r^{2}=0.86, p<0.01\right)$ particles. In addition, more than 99\% of SSA particles are internally mixed with nitrate (Fig. 3). This indicates that

233 chemistry in Reaction 2 (R2) is prevalent during long-range transport (Bondy et al., 2017). This is also consistent with previous studies regarding that nitric acid is a major contributor to chloride depletion (Zhao and Gao, 2008; Chi et al., 2015; AzadiAghdam et al., 2019). It is probably because the concentration of its precursor $\mathrm{NO}_{\mathrm{x}}\left(4.67 \mu \mathrm{g} \mathrm{m} \mathrm{m}^{-}\right.$ ${ }^{3}$ ) suppresses those of other acids in the south China sector (Wang et al., 2016; Wu et al., 2019).

Strong positive correlations between $\mathrm{Na}$ and organic acids are also observed in both the SSA-Aged $\left(r^{2}=0.52, p<0.01\right)$ and SSA-Bio particles $\left(r^{2}=0.61, p<0.01\right)$. Furthermore, very high number fractions (NFs) of organic acids are also found in SSAAged (72\%) and SSA-Bio (59\%), as shown in Fig. 3. This indicates the possible 
presence of organic salts in SSA particles and the substantial contribution of organic

acids to the chloride depletion. The detailed mixing state between SSA particles and several detected organic acids, as shown in Fig. S4, indicates that formate, oxalate, malonate, and glutarate are the dominant salts. The relative peak area (RPA) ratio (acids / (sulfate + nitrate + organic acids $))$ is further applied to roughly evaluate the relative contribution of different acids (nitric acid, sulfuric acid, and organic acids) to the chloride depletion of SSA particles (Fig. S5). In the ageing process of the SSA particles, nitrate occupies a large proportion in the SSA-Aged (63-96\%) and SSA-Bio particles (64-95\%), respectively. Notably, chloride depletion attributed to organic acids could account for $2-34 \%$ in the SSA-Aged particles and $2-29 \%$ in the SSA-Bio particles. The relative contribution of organic acids to chloride depletion has been reported to be higher than $30 \%$ at the eastern United States coast (Braun et al., 2017) and up to 40\% in Southeast Asia (AzadiAghdam et al., 2019). The contribution of sulfuric acids (0$10 \%$ versus $0-18 \%)$ is the lowest, although it shows positive correlation $\left(\mathrm{r}^{2}=0.24, p<\right.$ 0.01 versus $\left.r^{2}=0.54, p<0.01\right)$ for the SSA-Aged and SSA-Bio particles, respectively (Fig. 2). In addition, similar variations in peak areas of sulfate, nitrate and organic acids were observed in the SSA-Aged and SSA-Bio particles throughout the sampling period (Fig. S6), indicating a close connection of the formation mechanism between inorganic and organic acids.

\subsection{Effect of particle type on chloride depletion}

$\mathrm{Cl} / \mathrm{Na}$ value is typically applied to evaluate the ageing degree of SSA particles 
(Laskin et al., 2012; Bondy et al., 2017). There is a significant difference of $\mathrm{Cl} / \mathrm{Na}$ between the SSA-Aged (1.9\%) and SSA-Bio (5.4\%) particles (Fig. 4). This result reflects less chloride remaining in the SSA-Aged, attributed to more severe ageing. It might also be supported by relatively weak positive correlation $\left(\mathrm{r}^{2}=0.46, p<0.01\right)$ between $\mathrm{Na}$ and $\mathrm{Cl}$ (Fig. 2). This result may be explained by the influence of chemical composition and mixing state on the evolution of the SSA particles (Collins et al., 2014; Quinn et al., 2015; Sultana et al., 2017b). Additionally, concentration calculation was also further quantified the chloride depletion percentage using the following equation:

$$
\% \mathrm{Cl}^{-} \text {depletion }=\left(1.81 \times\left[\mathrm{Na}^{+}\right]-\left[\mathrm{Cl}^{-}\right]\right) /\left(1.81 \times\left[\mathrm{Na}^{+}\right]\right) \times 100 \%
$$
where $\left[\mathrm{Na}^{+}\right]$and $\left[\mathrm{Cl}^{-}\right]$are mass concentrations $\left(\mu \mathrm{g} \mathrm{m}{ }^{-3}\right)$, and 1.81 is the typical mass ratio of $\mathrm{Cl} / \mathrm{Na}$ in seawater (Zhao and Gao, 2008; Braun et al., 2017; AzadiAghdam et al., 2019). The overall $\% \mathrm{Cl}^{-}$for the total SSA particles varying from $55 \%$ to $99 \%$ with an average of $78 \%$ (detailed in Supplement Table S1), which is similar to the previous filed study in the PRD region reported by Chen et al. (2016). However, SSA particles are not the only source of chlorine ion in the atmosphere (Lightowlers et al., 1988). The excess $[\mathrm{Cl}]^{-}$produced by fuel combustion could lower the $\% \mathrm{Cl}^{-}$, which might explain the weak difference between the two assessment methods of ageing degree of SSA particles. Hence, both assessment methods could effectively evaluate the chloride depletion of SSA particles supported by a positive correlation $\left(\mathrm{r}^{2}=0.47, p\right.$ $<0.01$ ) (Fig. S7).

Further analysis indicates that organic matter of biological origin might play an important role in such inhibition of chloride depletion in the SSA-Bio particles. It is 
supported by the relationship between peak area ratio of $\mathrm{Cl} / \mathrm{Na}$ and the biological origin markers (-26 [CN] $]^{-},-42[\mathrm{CNO}]^{-},-63\left[\mathrm{PO}_{2}\right]^{-}$and $\left.-79\left[\mathrm{PO}_{3}\right]^{-}\right)$described in section 3.1. As shown in Fig. 5, peak area ratio of $\mathrm{Cl} / \mathrm{Na}$ exhibits an increasing trend with both phosphate $\left(-63\left[\mathrm{PO}_{2}\right]^{-},-79\left[\mathrm{PO}_{3}\right]^{-}\right)$and organic nitrogen $\left(-26[\mathrm{CN}]^{-}\right.$and $-42\left[\mathrm{CNO}^{-}\right)$. This direct evidence indicated phosphate might have a considerable effect on chloride depletion in SSA particles. The relationship between $\mathrm{Cl} / \mathrm{Na}$ and organic nitrogen is also consistent with that reported in our previous filed observations at the same site (Lin et al., 2019). Previous laboratory study results have also shown that reactivity could be inhibited by the organic matter of biological origin (Ault et al., 2014). As shown in Fig. S8, transmission electron microscopy (TEM) images clearly show $\mathrm{NaCl}$ core and organic coating of the SSA particles with various thicknesses. The thicker organic coating may inhibit the reactive uptake of $\mathrm{HNO}_{3(g)}$ or $\mathrm{N}_{2} \mathrm{O}_{5(g)}$ to SSA particles (Folkers et al., 2003; Ryder et al., 2014; Ryder et al., 2015), resulting in a less released $\mathrm{Cl}$ to the atmosphere. Such organic coatings are mostly composed of long-chain hydrocarbon, saccharides, carbohydrate, amine and anionic surfactant (Jayarathne et al., 2016; Bertram et al., 2018), and thus have stronger hydrophobicity and probably inhibit the occurrence of $\mathrm{Cl}$ transport of convection and diffusion (Bondy et al., 2017).

\section{Conclusion and atmospheric implication}

We investigated the chloride depletion of SSA particles after long-range inland transport in south China, during a monsoon season. The SSA particles still account for $\sim 3 \%$ of the observed submicron particles and are extensively internally mixed with 
various acids. While the contribution of nitric acid dominates over other acids to the

chloride depletion, our results suggest that the role of organic acids should not be neglected. Up to $34 \%$ of chloride depletion could be explained by diverse organic acids. Our results add to the growing body of evidence that carboxylic acid may play a significant role in acid displacement reactions (Ma et al., 2013). Given the substantial influence of organic acids on the hygroscopic properties of SSA (Ghorai et al., 2014), such processes may affect CCN / IN activities and lifetime of SSA (Knopf et al., 2014), and thus should be considered in models to predict the climate impact of SSA accurately. Currently, the calculation model of organic acids (especially water-soluble organic compounds) to chloride depletion is still limited (Laskin et al., 2012; Xu et al., 2013). Peng et al. (2016) suggested organic salts produced by $\mathrm{NaCl}$ react with dicarboxylic acids inhibit the volatilization of $\mathrm{HCl}$ that is resulting in less chloride depletion. Our data may improve the understanding of chloride depletion responsible for mixing state of diverse organic acids in the future study.

In addition, we stress that there is a SSA type (e.g., SSA-Bio) likely attributed to the biogenic origin, exhibiting distinctly different chloride depletion, in comparison with the commonly observed SSA-Aged type. Our data indicate that organic matter of biological origin might play an essential role in such inhibition of chloride depletion in the SSA-Bio particles. As previously reported, the presence of organic coatings on SSA particles could effectively influence the heterogeneous reactivity of SSA particles (Ryder et al., 2015; Bondy et al., 2017). Considering the considerable contribution $(\sim 50 \%)$ of the SSA-Bio particles to the overall SSA, such information should be useful 


\section{Author contributions}

\section{References}

GHZ, LL, and XHB designed the research. BJS, GHZ, and LL analyzed the data, and wrote the manuscript. YZF, XBD, YC, YXY and WS conducted sampling work under the guidance of GHZ, LL, and XHB. DHC had an active role in supporting the sampling work. YZF performed the laboratory analysis of individual particles by TEM/EDS. All authors contributed to the discussions of the results and refinement of the manuscript.

Data availability. Data are available on request from Lei Li (lileishdx@163.com).

\section{Acknowledgement}

This work was supported by the National Nature Science Foundation of China (No. 41905106), Guangdong International Science and Technology Cooperation Project (2018A050506020) and Guangdong Foundation for Program of Science and Technology Research (Grant No. 2019B121205006).

Competing interests. The authors declare that they have no conflict of interest. 
M, Horn,Scott C, Russell,Gregg A, Czerwieniec, Carlito B, Lebrilla,Eric E, Gard,Matthias, Frank., Maurice E, P., Paul T, S., Herbert J, T., David P, F., Joanne M, H., Scott C, R., Gregg A, C., Carlito B, L., Eric E, G., and Matthias, F.: Comprehensive Assignment of Mass Spectral Signatures from Individual Bacillus atrophaeus Spores in Matrix-Free Laser Desorption/Ionization Bioaerosol Mass Spectrometry, Anal. Chem., 77, 3315-3323, http://doi.org/10.1021/ac048298p, 2005.

Arndt, J., Sciare, J., Mallet, M., Roberts, G. C., Marchand, N., Sartelet, K., Sellegri, K., Dulac, F., Healy, R. M., and Wenger, J. C.: Sources and mixing state of summertime background aerosol in the north-western Mediterranean basin, Atmos. Chem. Phys, 17, 6975-7001, http://doi.org/10.5194/acp-17-6975-2017, 2017.

Ault, A. P., Moffet, R. C., Baltrusaitis, J., Collins, D. B., Ruppel, M. J., CuadraRodriguez, L. A., Zhao, D. F., Guasco, T. L., Ebben, C. J., Geiger, F. M., Bertram, T. H., Prather, K. A., and Grassian, V. H.: Size-Dependent Changes in Sea Spray Aerosol Composition and Properties with Different Seawater Conditions, Environ. Sci. Technol., 47, 5603-5612, http://doi.org/10.1021/es400416g, 2013.

Ault, A. P., Guasco, T. L., Baltrusaitis, J., Ryder, O. S., Trueblood, J. V., Collins, D. B., Ruppel, M. J., Cuadra-Rodriguez, L. A., Prather, K. A., and Grassian, V. H.: Heterogeneous reactivity of nitric acid with nascent sea spray aerosol: Large differences observed between and within individual particles, J. Phys. Chem. 
Lett., 5, 2493-2500, http://doi.org/10.1021/jz5008802, 2014.

Axson, J. L., May, N. W., Colon-Bernal, I. D., Pratt, K. A., and Ault, A. P.: Lake Spray Aerosol: A Chemical Signature from Individual Ambient Particles, Environ. Sci. Technol., 50, 9835-9845, http://doi.org/10.1021/acs.est.6b01661, 2016.

AzadiAghdam, M., Braun, R. A., Edwards, E.-L., Bañaga, P. A., Cruz, M. T., Betito, G., Cambaliza, M. O., Dadashazar, H., Lorenzo, G. R., Ma, L., MacDonald, A. B., Nguyen, P., Simpas, J. B., Stahl, C., and Sorooshian, A.: On the nature of sea salt aerosol at a coastal megacity: Insights from Manila, Philippines in Southeast Asia, Atmos. Environ., 216 http://doi.org/10.1016/j.atmosenv.2019.116922, 2019.

Bertram, T. H., Cochran, R. E., Grassian, V. H., and Stone, E. A.: Sea spray aerosol chemical composition: elemental and molecular mimics for laboratory studies of heterogeneous and multiphase reactions, Chem. Soc. Rev., 47, 2374-2400, http://doi.org/10.1039/c7cs00008a, 2018.

Bikkina, S., Kawamura, K., and Miyazaki, Y.: Latitudinal distributions of atmospheric dicarboxylic acids, oxocarboxylic acids, and $\alpha$-dicarbonyls over the western North Pacific: Sources and formation pathways, J. Geophys. Res. Atmos., 120, 5010-5035, http://doi.org/10.1002/2014jd022235, 2015.

Bondy, A. L., Wang, B., Laskin, A., Craig, R. L., Nhliziyo, M. V., Bertman, S. B., Pratt, K. A., Shepson, P. B., and Ault, A. P.: Inland sea spray aerosol transport and incomplete chloride depletion: Varying degrees of reactive processing observed during soas, Environ. Sci. Technol., 51, 9533-9542, 
http://doi.org/10.1021/acs.est.7b02085, 2017.

Braun, R. A., Dadashazar, H., MacDonald, A. B., Aldhaif, A. M., Maudlin, L. C., Crosbie, E., Aghdam, M. A., Hossein Mardi, A., and Sorooshian, A.: Impact of Wildfire Emissions on Chloride and Bromide Depletion in Marine Aerosol Particles, Environ. Sci. Technol., 51, 9013-9021, http://doi.org/10.1021/acs.est.7b02039, 2017.

Chen, W., Wang, X., Cohen, J. B., Zhou, S., Zhang, Z., Chang, M., and Chan, C.-Y.: Properties of aerosols and formation mechanisms over southern China during the monsoon season, Atmos. Chem. Phys., 16, 13271-13289, http://doi.org/10.5194/acp-16-13271-2016, 2016.

Cheng, C., Huang, Z., Chan, C. K., Chu, Y., Li, M., Zhang, T., Ou, Y., Chen, D., Cheng, P., Li, L., Gao, W., Huang, Z., Huang, B., Fu, Z., and Zhou, Z.: Characteristics and mixing state of amine-containing particles at a rural site in the Pearl River Delta, China, Atmos. Chem. Phys., 18, 9147-9159, http://doi.org/10.5194/acp18-9147-2018, 2018.

Chi, J. W., Li, W. J., Zhang, D. Z., Zhang, J. C., Lin, Y. T., Shen, X. J., Sun, J. Y., Chen, J. M., Zhang, X. Y., Zhang, Y. M., and Wang, W. X.: Sea salt aerosols as a reactive surface for inorganic and organic acidic gases in the Arctic troposphere, Atmos. Chem. Phys., 15, 11341-11353, http://doi.org/10.5194/acp-15-11341-2015, 2015.

Cochran, R. E., Laskina, O., Trueblood, J. V., Estillore, A. D., Morris, H. S., Jayarathne, T., Sultana, C. M., Lee, C., Lin, P., Laskin, J., Laskin, A., Dowling, J. A., Qin, 
Z., Cappa, C. D., Bertram, T. H., Tivanski, A. V., Stone, E. A., Prather, K. A., and Grassian, V. H.: Molecular Diversity of Sea Spray Aerosol Particles: Impact of Ocean Biology on Particle Composition and Hygroscopicity, Chem., 2, 655-667, http://doi.org/10.1016/j.chempr.2017.03.007, 2017a.

Cochran, R. E., Ryder, O. S., Grassian, V. H., and Prather, K. A.: Sea Spray Aerosol: The Chemical Link between the Oceans, Atmosphere, and Climate, Acc. Chem. Res., 50, 599-604, http://doi.org/10.1021/acs.accounts.6b00603, 2017 b.

Collins, D. B., Ault, A. P., Moffet, R. C., Ruppel, M. J., Cuadra-Rodriguez, L. A., Guasco, T. L., Corrigan, C. E., Pedler, B. E., Azam, F., Aluwihare, L. I., Bertram, T. H., Roberts, G. C., Grassian, V. H., and Prather, K. A.: Impact of marine biogeochemistry on the chemical mixing state and cloud forming ability of nascent sea spray aerosol, J. Geophys. Res. Atmos., 118, 8553-8565, http://doi.org/10.1002/jgrd.50598, 2013.

Collins, D. B., Zhao, D. F., Ruppel, M. J., Laskina, O., Grandquist, J. R., Modini, R. L., Stokes, M. D., Russell, L. M., Bertram, T. H., Grassian, V. H., Deane, G. B., and Prather, K. A.: Direct aerosol chemical composition measurements to evaluate the physicochemical differences between controlled sea spray aerosol generation schemes, Atmos. Meas. Tech., 7, 3667-3683, http://doi.org/10.5194/amt-7-3667-2014, 2014.

Czerwieniec., G. A., Russell., S. C., Tobias., H. J., Pitesky., M. E., Fergenson., D. P., Steele., P., Srivastava., A., Horn., J. M., Frank., M., Gard., E. E., and Lebrilla., C. B.: Stable Isotope Labeling of Entire Bacillus atrophaeus Spores and 
Vegetative Cells Using Bioaerosol Mass Spectrometry, Anal. Chem., 77, 10811087, http://doi.org/10.1021/ac0488098, 2005.

Dasgupta, P. K., Campbell, S. W., Al-Horr, R. S., Ullah, S. M. R., Li, J., Amalfitano, C., and Poor, N. D.: Conversion of sea salt aerosol to NaNO3 and the production of $\mathrm{HCl}$ : Analysis of temporal behavior of aerosol chloride/nitrate and gaseous $\mathrm{HCl} / \mathrm{HNO} 3$ concentrations with AIM, Atmos. Environ., 41, 4242-4257, http://doi.org/10.1016/j.atmosenv.2006.09.054, 2007.

Drozd, G., Woo, J., Häkkinen, S. A. K., Nenes, A., and McNeill, V. F.: Inorganic salts interact with oxalic acid in submicron particles to form material with low hygroscopicity and volatility, Atmos. Chem. Phys., 14, 5205-5215, http://doi.org/10.5194/acp-14-5205-2014, 2014.

Fergenson, P. D. M. E. P., Herbert J. Tobias, Paul T. Steele, Gregg A. Czerwieniec, Scott C. Russell, Carlito B. Lebrilla, Joanne M. Horn, Keith R. Coffee, Abneesh Srivastava, Segaran P. Pillai, Meng-Ta Peter Shih, Howard L. Hall, Albert J. Ramponi, John T. Chang, Richard G. Langlois, Pedro L. Estacio, Robert T. Hadley, Matthias Frank, and Eric E. Gard*,: Reagentless Detection and Classification of Individual Bioaerosol Particles in Seconds, Anal. Chem., 76, 373-378, http://doi.org/10.1021/ac034467e, 2004.

Finlayson-Pitts, B. J.: The tropospheric chemistry of sea salt: A molecular-level view of the chemistry of nacl and nabr, Chem. Rev. , 103, 4801-4822, http://doi.org/10.1021/cr020653t, 2003.

Folkers, M., Mentel, T. F., and Wahner, A.: Influence of an organic coating on the 
reactivity of aqueous aerosols probed by the heterogeneous hydrolysis of N2O5, Geophys. Res. Lett., 30, http://doi.org/10.1029/2003g1017168, 2003.

Gantt, B., and Meskhidze, N.: The physical and chemical characteristics of marine primary organic aerosol: a review, Atmos. Chem. Phys., 13, 3979-3996, http://doi.org/10.5194/acp-13-3979-2013, 2013.

Gaston, C. J., Pratt, K. A., Qin, X. Y., and Prather, K. A.: Real-Time Detection and Mixing State of Methanesulfonate in Single Particles at an Inland Urban Location during a Phytoplankton Bloom, Environ. Sci. Technol., 44, 15661572, http://doi.org/10.1021/es902069d, 2010.

Ghorai, S., Wang, B., Tivanski, A., and Laskin, A.: Hygroscopic properties of internally mixed particles composed of $\mathrm{NaCl}$ and water-soluble organic acids, Environ. Sci. Technol., 48, 2234-2241, http://doi.org/10.1021/es404727u, 2014.

Guasco, T. L., Cuadra-Rodriguez, L. A., Pedler, B. E., Ault, A. P., Collins, D. B., Zhao, D. F., Kim, M. J., Ruppel, M. J., Wilson, S. C., Pomeroy, R. S., Grassian, V. H., Azam, F., Bertram, T. H., and Prather, K. A.: Transition Metal Associations with Primary Biological Particles in Sea Spray Aerosol Generated in a Wave Channel, Environ. Sci. Technol., 48, 1324-1333, http://doi.org/10.1021/es403203d, 2014.

Hughes, L. S., Allen, J. O., Bhave, P., Kleeman, M. J., Cass, G. R., Liu, D. Y., Fergenson, D. F., Morrical, B. D., and Prather, K. A.: Evolution of atmospheric particles along trajectories crossing the Los Angeles basin, Environ. Sci. Technol., 34, 3058-3068, http://doi.org/10.1021/es9908671, 2000. 
Jayarathne, T., Sultana, C. M., Lee, C., Malfatti, F., Cox, J. L., Pendergraft, M. A., Moore, K. A., Azam, F., Tivanski, A. V., Cappa, C. D., Bertram, T. H., Grassian, V. H., Prather, K. A., and Stone, E. A.: Enrichment of saccharides and divalent cations in sea spray aerosol during two phytoplankton blooms, Environ. Sci. Technol., 50, 11511-11520, http://doi.org/10.1021/acs.est.6b02988, 2016.

Kawamura, K., and Bikkina, S.: A review of dicarboxylic acids and related compounds in atmospheric aerosols: Molecular distributions, sources and transformation, Atmos. Res., 170, 140-160, http://doi.org/10.1016/j.atmosres.2015.11.018, 2016.

Knopf, D. A., Alpert, P. A., Wang, B., O'Brien, R. E., Kelly, S. T., Laskin, A., Gilles, M. K., and Moffet, R. C.: Microspectroscopic imaging and characterization of individually identified ice nucleating particles from a case field study, J. Geophys. $\quad$ Res. $\quad$ Atmos., 119, 10,365-310,381, http://doi.org/10.1002/2014jd021866, 2014.

Laskin, A., Moffet, R. C., Gilles, M. K., Fast, J. D., Zaveri, R. A., Wang, B., Nigge, P., and Shutthanandan, J.: Tropospheric chemistry of internally mixed sea salt and organic particles: Surprising reactivity of $\mathrm{NaCl}$ with weak organic acids, J. Geophys. Res. Atmos., 117, n/a-n/a, http://doi.org/10.1029/2012jd017743, 2012.

Li, L., Huang, Z., Dong, J., Li, M., Gao, W., Nian, H., Fu, Z., Zhang, G., Bi, X., Cheng, P., and Zhou, Z.: Real time bipolar time-of-flight mass spectrometer for analyzing single aerosol particles, Int. J. Mass Spectrom., 303, 118-124, 
http://doi.org/10.1016/j.ijms.2011.01.017, 2011.

Lightowlers, P. J., and Cape, J. N.: Sources and fate of atmospheric $\mathrm{HCl}$ in the U.K. and western Europe, Atmos. Environ., 22, 7-15, http://doi.org/10.1016/00046981(88)90294-6, 1988.

Lin, Q., Yang, Y., Fu, Y., Zhang, G., Jiang, F., Peng, L., Lian, X., Liu, F., Bi, X., Li, L., Chen, D., Li, M., Ou, J., Tang, M., Wang, X., Peng, P., amp, apos, an, and Sheng, G.: Enrichment of submicron sea-salt-containing particles in small cloud droplets based on single-particle mass spectrometry, Atmos. Chem. Phys., 19, 10469-10479, http://doi.org/10.5194/acp-19-10469-2019, 2019.

Ma, Q., Ma, J., Liu, C., Lai, C., and He, H.: Laboratory study on the hygroscopic behavior of external and internal $\mathrm{C} 2-\mathrm{C} 4$ dicarboxylic acid- $\mathrm{NaCl}$ mixtures, Environ. Sci. Technol., 47, 10381-10388, http://doi.org/10.1021/es4023267, 2013.

Ma, X., von Salzen, K., and Li, J.: Modelling sea salt aerosol and its direct and indirect effects on climate, Atmos. Chem. Phys., 8, 1311-1327, http://doi.org/doi.org/10.5194/acp-8-1311-2008, 2008.

Martin, A. C., Cornwell, G. C., Atwood, S. A., Moore, K. A., Rothfuss, N. E., Taylor, H., DeMott, P. J., Kreidenweis, S. M., Petters, M. D., and Prather, K. A.: Transport of pollution to a remote coastal site during gap flow from California's interior: impacts on aerosol composition, clouds, and radiative balance, Atmos. Chem. Phys., 17, 1491-1509, http://doi.org/10.5194/acp-17-1491-2017, 2017. May, N. W., Gunsch, M. J., Olson, N. E., Bondy, A. L., Kirpes, R. M., Bertman, S. B., 
China, S., Laskin, A., Hopke, P. K., Ault, A. P., and Pratt, K. A.: Unexpected Contributions of Sea Spray and Lake Spray Aerosol to Inland Particulate Matter, Environ. Sci. Technol., 5, 405-412, http://doi.org/10.1021/acs.estlett.8b00254, 2018.

Mochida, M., Umemoto, N., Kawamura, K., and Uematsu, M.: Bimodal size distribution of C2-C4 dicarboxylic acids in the marine aerosols, J. Geophys. Res. Lett., 30, http://doi.org/10.1029/2003g1017451, 2003.

Nguyen, Q. T., Kjær, K. H., Kling, K. I., Boesen, T., and Bilde, M.: Impact of fatty acid coating on the CCN activity of sea salt particles, Tellus. B., 69, http://doi.org/10.1080/16000889.2017.1304064, 2017.

O'Dowd, C., Ceburnis, D., Ovadnevaite, J., Vaishya, A., Rinaldi, M., and Facchini, M. C.: Do anthropogenic, continental or coastal aerosol sources impact on a marine aerosol signature at Mace Head?, Atmos. Chem. Phys., 14, 1068710704, http://doi.org/10.5194/acp-14-10687-2014, 2014.

Peng, C., Jing, B., Guo, Y. C., Zhang, Y. H., and Ge, M. F.: Hygroscopic Behavior of Multicomponent Aerosols Involving $\mathrm{NaCl}$ and Dicarboxylic Acids, J. Phys. Chem. A, 120, 1029-1038, http://doi.org/10.1021/acs.jpca.5b09373, 2016.

Prather, K. A., Bertram, T. H., Grassian, V. H., Deane, G. B., Stokes, M. D., DeMott, P. J., Aluwihare, L. I., Palenik, B. P., Azam, F., Seinfeld, J. H., Moffet, R. C., Molina, M. J., Cappa, C. D., Geiger, F. M., Roberts, G. C., Russell, L. M., Ault, A. P., Baltrusaitis, J., Collins, D. B., Corrigan, C. E., Cuadra-Rodriguez, L. A., Ebben, C. J., Forestieri, S. D., Guasco, T. L., Hersey, S. P., Kim, M. J., Lambert, 
W. F., Modini, R. L., Mui, W., Pedler, B. E., Ruppel, M. J., Ryder, O. S., Schoepp, N. G., Sullivan, R. C., and Zhao, D. F.: Bringing the ocean into the laboratory to probe the chemical complexity of sea spray aerosol, P. Natl. Acad. Sci. USA., 110, 7550-7555, http://doi.org/10.1073/pnas.1300262110, 2013.

Quinn, P. K., Collins, D. B., Grassian, V. H., Prather, K. A., and Bates, T. S.: Chemistry and related properties of freshly emitted sea spray aerosol, Chem. Rev., 115, 4383-4399, http://doi.org/10.1021/cr500713g, 2015.

Ryder, O. S., Ault, A. P., Cahill, J. F., Guasco, T. L., Riedel, T. P., Cuadra-Rodriguez, L. A., Gaston, C. J., Fitzgerald, E., Lee, C., Prather, K. A., and Bertram, T. H.: On the Role of Particle Inorganic Mixing State in the Reactive Uptake of N2O5 to Ambient Aerosol Particles, Environ. Sci. Technol., 48, 1618-1627, http://doi.org/10.1021/es4042622, 2014.

Ryder, O. S., Campbell, N. R., Morris, H., Forestieri, S., Ruppel, M. J., Cappa, C., Tivanski, A., Prather, K., and Bertram, T. H.: Role of organic coatings in regulating n2o5 reactive uptake to sea spray aerosol, J. Phys. Chem. A, 119, 11683-11692, http://doi.org/10.1021/acs.jpca.5b08892, 2015.

Song, X., and Hopke, P. K.: Classification of single particles analyzed by ATOFMS using an artificial neural network, ART-2A, Anal. Chem., 71, 860-865, http://doi.org/10.1021/ac9809682, 1999.

Sultana, C. M., Al-Mashat, H., and Prather, K. A.: Expanding Single Particle Mass Spectrometer Analyses for the Identification of Microbe Signatures in Sea Spray Aerosol, Anal. Chem., 89, 10162-10170, 
Sultana, C. M., Collins, D. B., and Prather, K. A.: Effect of Structural Heterogeneity in Chemical Composition on Online Single-Particle Mass Spectrometry Analysis of Sea Spray Aerosol Particles, Environ. Sci. Technol., 51, 3660-3668, http://doi.org/10.1021/acs.est.6b06399, 2017 b.

Trueblood, J. V., Estillore, A. D., Lee, C., Dowling, J. A., Prather, K. A., and Grassian, V. H.: Heterogeneous Chemistry of Lipopolysaccharides with Gas-Phase Nitric Acid: Reactive Sites and Reaction Pathways, J. Phys. Chem. A., 120, 6444-6450, http://doi.org/10.1021/acs.jpca.6b07023, 2016.

Wang, B., and Laskin, A.: Reactions between water-soluble organic acids and nitrates in atmospheric aerosols: Recycling of nitric acid and formation of organic salts, J. Geophys. Res. Atmos., 119, 3335-3351, http://doi.org/10.1002/2013JD021169, 2014.

Wang, B., O'Brien, R. E., Kelly, S. T., Shilling, J. E., Moffet, R. C., Gilles, M. K., and Laskin, A.: Reactivity of liquid and semisolid secondary organic carbon with chloride and nitrate in atmospheric aerosols, J. Phys. Chem. A., 119, 44984508, http://doi.org/10.1021/jp510336q, 2015.

Wang, N., Lyu, X. P., Deng, X. J., Guo, H., Deng, T., Li, Y., Yin, C. Q., Li, F., and Wang, S. Q.: Assessment of regional air quality resulting from emission control in the Pearl River Delta region, southern China, Sci. Total. Environ., 573, 1554-1565, http://doi.org/10.1016/j.scitotenv.2016.09.013, 2016.

Wang, X. F., Deane, G. B., Moore, K. A., Ryder, O. S., Stokes, M. D., Beall, C. M., 
Collins, D. B., Santander, M. V., Burrows, S. M., Sultana, C. M., and Prather, K. A.: The role of jet and film drops in controlling the mixing state of submicron sea spray aerosol particles, P. Natl. Acad. Sci. USA., 114, 69786983, http://doi.org/10.1073/pnas.1702420114, 2017.

Wu, Z., Zhang, Y., Zhang, L., Huang, M., Zhong, L., Chen, D., and Wang, X.: Trends of outdoor air pollution and the impact on premature mortality in the Pearl River Delta region of southern China during 2006-2015, Sci. Total. Environ., 690, 248-260, http://doi.org/10.1016/j.scitotenv.2019.06.401, 2019.

Xu, G., Gao, Y., Lin, Q., Li, W., and Chen, L.: Characteristics of water-soluble inorganic and organic ions in aerosols over the Southern Ocean and coastal East Antarctica during austral summer, J. Geophys. Res. Atmos., 118, 13,303313,318, http://doi.org/10.1002/2013jd019496, 2013.

Zawadowicz, M. A., Froyd, K. D., Murphy, D. M., and Cziczo, D. J.: Improved identification of primary biological aerosol particles using single-particle mass spectrometry, Atmos. Chem. Phys., 17, 7193-7212, http://doi.org/10.5194/acp17-7193-2017, 2017.

Zhang, G., Lin, Q., Peng, L., Yang, Y., Fu, Y., Bi, X., Li, M., Chen, D., Chen, J., Cai, Z., Wang, X., Peng, P., Sheng, G., and Zhou, Z.: Insight into the in-cloud formation of oxalate based on in situ measurement by single particle mass spectrometry, Atmos. Chem. Phys., 17, 13891-13901, https://doi.org/10.5194/acp-17-13891-2017, 2017.

Zhao, Y., and Gao, Y.: Acidic species and chloride depletion in coarse aerosol particles 
https://doi.org/10.5194/acp-2020-443

Preprint. Discussion started: 8 June 2020

(c) Author(s) 2020. CC BY 4.0 License.

611 in the US east coast, Sci. Total. Environ., 407, 541-547,

$612 \quad$ http://doi.org/10.1016/j.scitotenv.2008.09.002, 2008. 

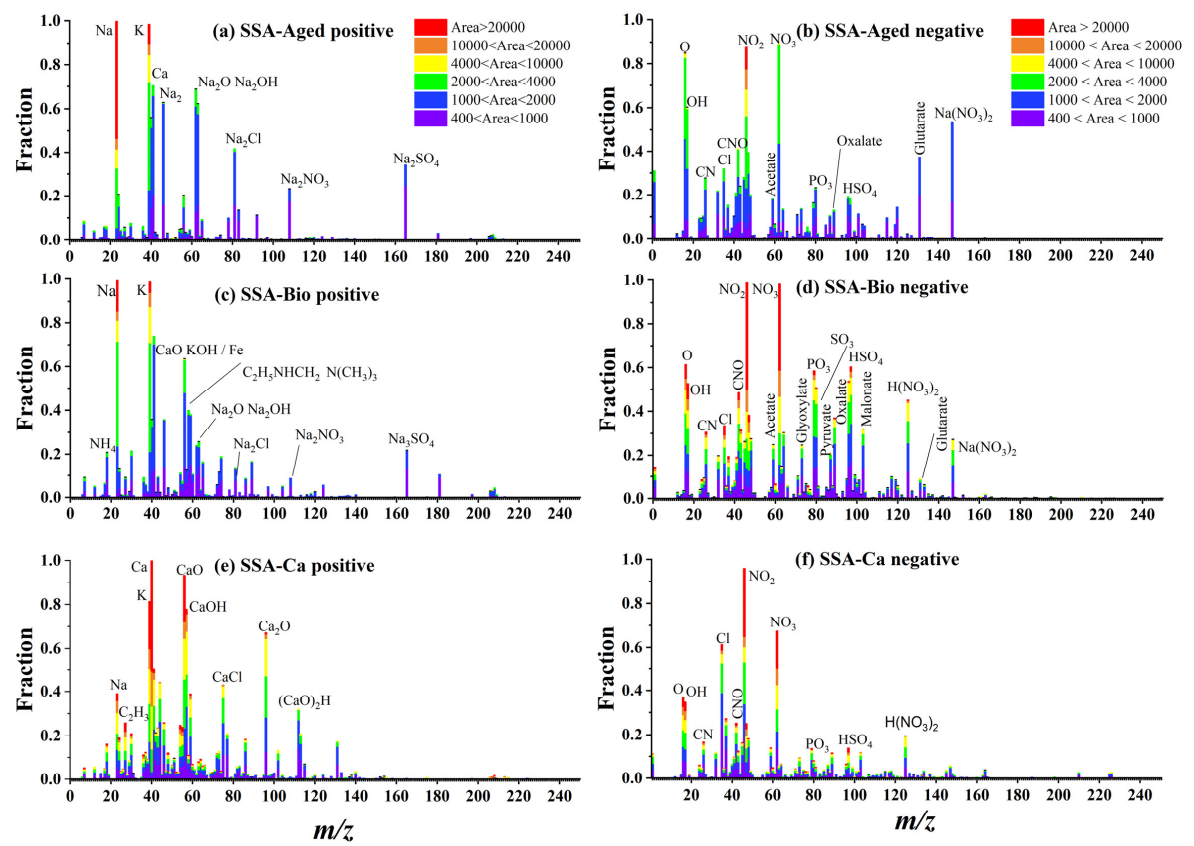

Figure 1. The averaged digitized positive and negative ion mass spectra of the major 
https://doi.org/10.5194/acp-2020-443

Preprint. Discussion started: 8 June 2020

(c) Author(s) 2020. CC BY 4.0 License.

(c) (i)
Atmospheric

Chemistry

and Physics

Discussions
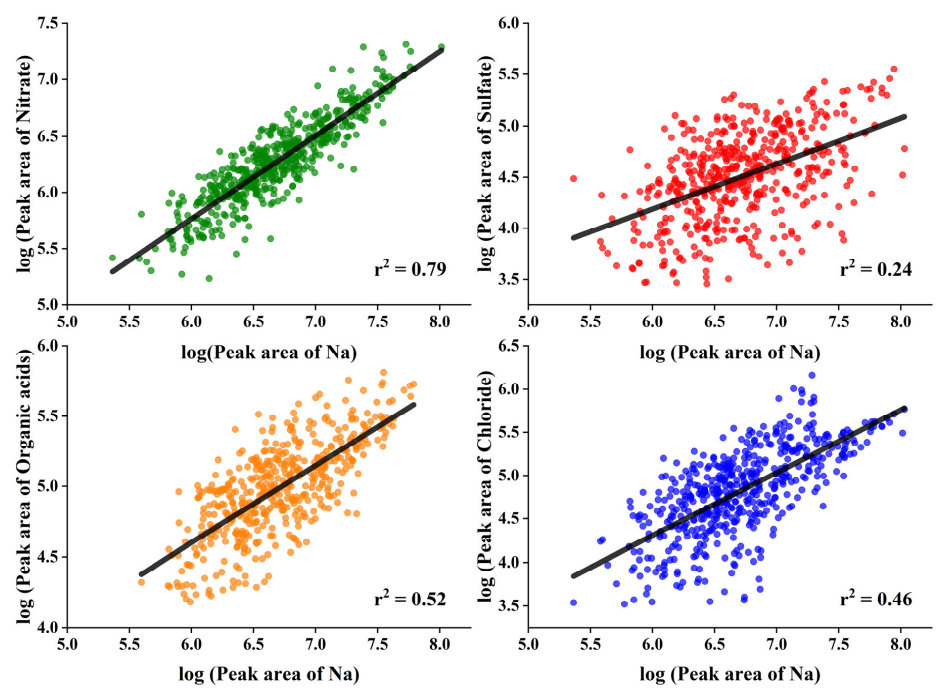

618

(a) SSA-Aged
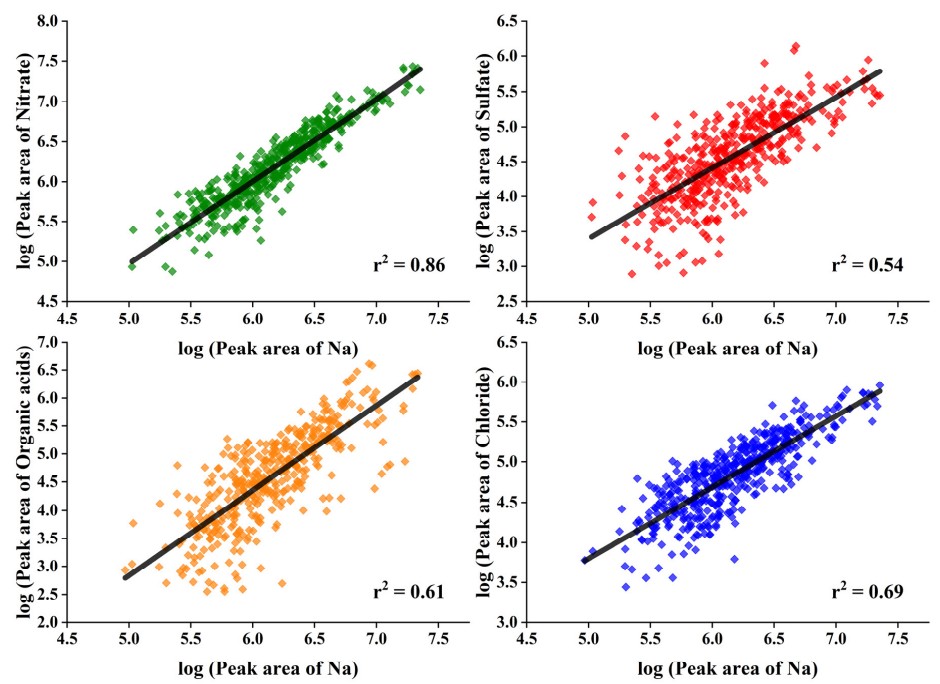

619

(b) SSA-Bio

620 Figure 2. Correlations between hourly mean peak area of $\mathrm{Na}(\mathrm{m} / \mathrm{z} 23)$ and sulfate $(\mathrm{m} / \mathrm{z}$

$621-97)$, nitrate $(\mathrm{m} / \mathrm{z}-46$ and 62$)$, organic acids $(\mathrm{m} / \mathrm{z}-45,-59,-73,-87,-89,-103,-117$ and

$622-131)$ and chloride $(m / z-35$ and -37$)$ in the SSA-Aged and SSA-Bio. The data is

623 logarithmically transformed to follow a normal distribution. 


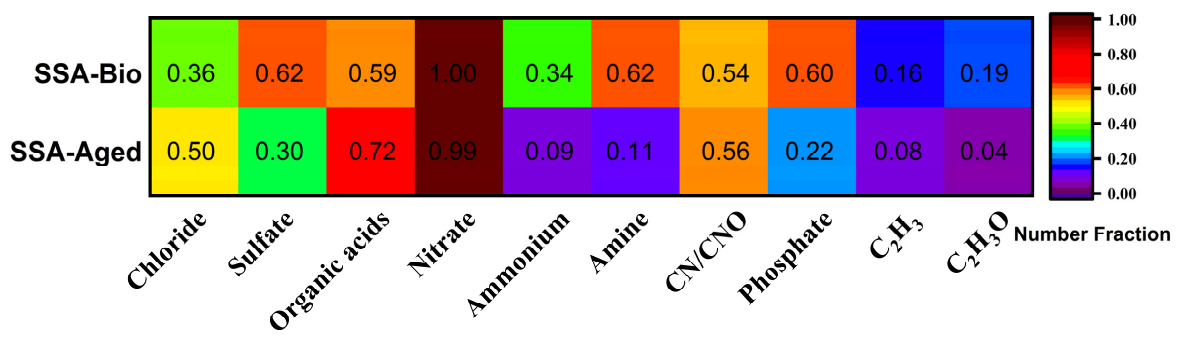

625 Figure 3. Hourly mean number fractions (NFs) of major component in the SSA-Aged 626 and SSA-Bio. The major component includes chloride $(\mathrm{m} / \mathrm{z}-35$ or -37$)$, sulfate $(\mathrm{m} / \mathrm{z}-$

$62797)$, organic acids $(\mathrm{m} / \mathrm{z}-45,-59,-73,-87,-89,-103,-117$ or -131$)$, nitrate $(\mathrm{m} / \mathrm{z}-46$ or -

628 62), ammonium ( $\mathrm{m} / \mathrm{z} 18)$, amine ( $\mathrm{m} / \mathrm{z} 58$ and 59$)$, organic nitrogen $(\mathrm{m} / \mathrm{z}-26$ or -42$)$,

629 phosphate $(\mathrm{m} / \mathrm{z}-63$ or -79$)$, and organic carbon $(\mathrm{m} / \mathrm{z} 27$ and 43$)$. 


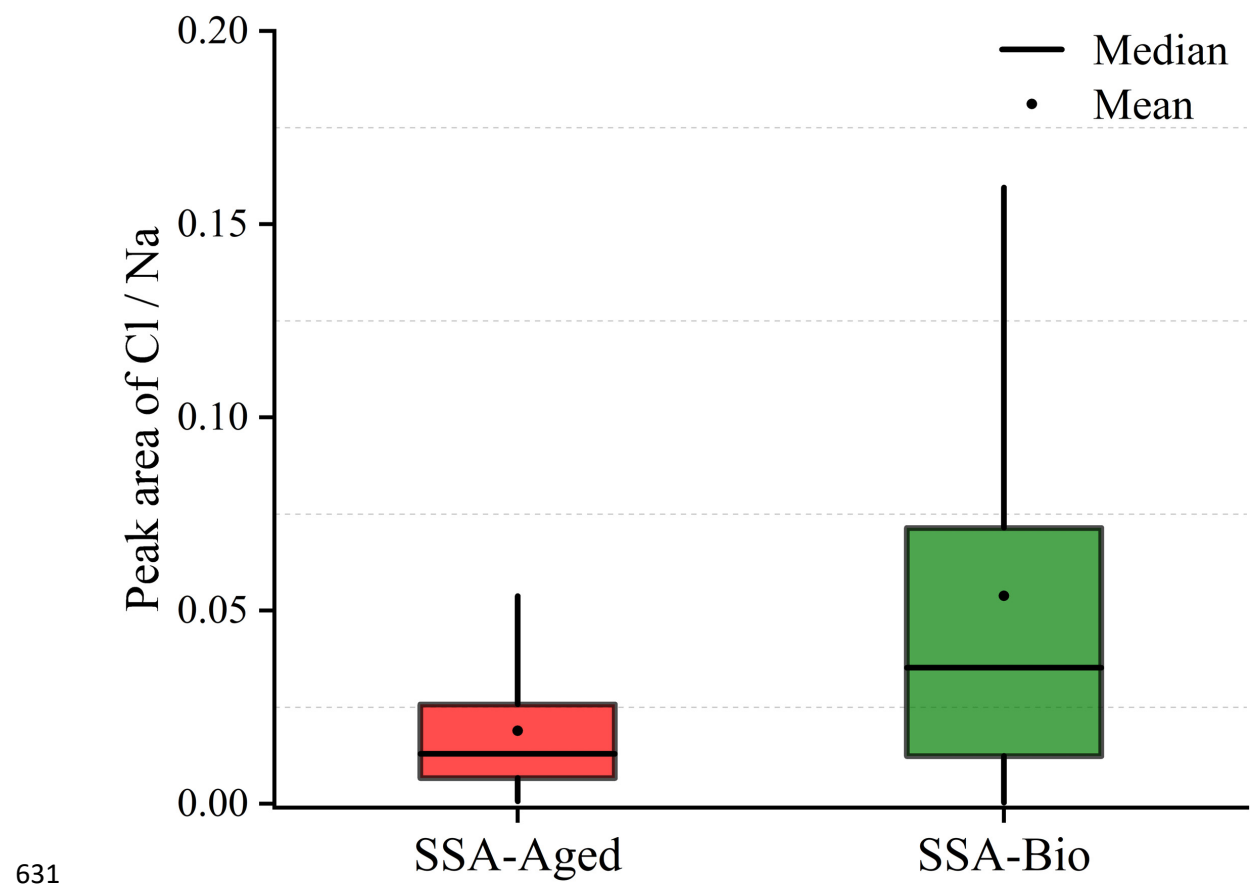

632 Figure 4. A box and whisker plot of hourly mean peak area of $\mathrm{Cl} / \mathrm{Na}$ in SSA-Aged

633 and SSA-Bio. In the box and whisker plot, the lower and upper lines of the box denote

634 the 25 and 75 percentiles, respectively. The lower and upper edges denote the 10 and 63590 percentiles, respectively. 

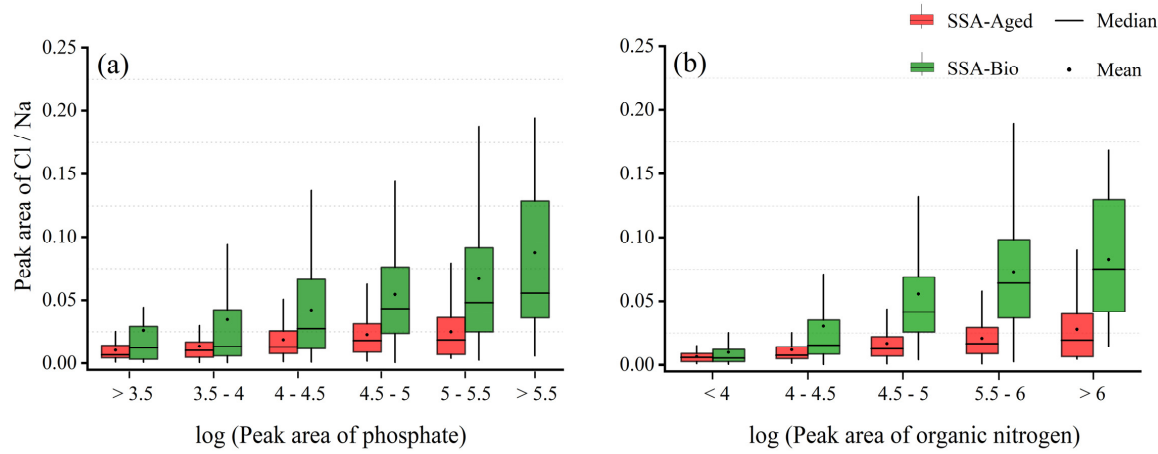

636

Figure 5. The logarithmical peak area of phosphate $(\mathrm{m} / \mathrm{z}-63$ and -79$)$ and organic

638 nitrogen $(\mathrm{m} / \mathrm{z}-26$ and -42$)$ varied as a function of hourly mean peak area ratio of $\mathrm{Cl}$ /

639 Na. 